\title{
Evaluation of therapy with cabergoline in men with macroprolactinoma
}

\section{Ocena skuteczności leczenia kabergoliną mężczyzn z makroprolaktinoma}

\author{
Elżbieta Andrysiak-Mamos', Agnieszka Kaźmierczyk-Puchalska', Ewa Żochowska1, \\ Elżbieta Sowińska-Przepiera1, Leszek Sagan², Ireneusz Kojder³, Anhelli Syrenicz' \\ ${ }^{1}$ Klinika Endokrynologii, Chorób Metabolicznych i Chorób Wewnętrznych Pomorskiego Uniwersytetu Medycznego w Szczecinie
ul. Unii Lubelskiej 1, 71-252 Szczecin \\ Kierownik: prof. dr hab. n. med. Anhelli Syrenicz
}

2 Oddział Kliniczny Neurochirurgii i Neurochirurgii Dziecięcej Pomorskiego Uniwersytetu Medycznego w Szczecinie ul. Mączna 4, 70-780 Szczecin

Kierownik: dr hab. n. med. Leszek Sagan

${ }^{3}$ Katedra i Klinika Neurochirurgii Pomorskiego Uniwersytetu Medycznego w Szczecinie

ul. Unii Lubelskiej 1, 71-252 Szczecin

Kierownik: prof. dr hab. n. med. Ireneusz Kojder

\section{SUMMARY}

Introduction: Pituitary gland adenomas producing prolactin are one of the commonest hormonally active tumours. Pharmacological treatment using of dopamine receptors agonists is the therapy of choice in a case of prolactinoma. Bromocriptine, which causes numerous side-effects is the most commonly used drug. Recently, good results of therapy have been achieved with cabergoline - a selective dopamine receptor agonist with prolonged time of action.

The aim of the study was to evaluate therapy with cabergoline of men with macroprolactinoma based on clinical, hormonal and radiological examinations.

Material and methods: Ten men aged 18-65 (mean $41.9 \pm 15.01$ years) with the presence of a pathological mass in the pituitary gland sized between 16.7 and $40.5 \mathrm{~mm}$ (mean $29.8 \pm 9.38 \mathrm{~mm}$ ) and an elevated prolactin (PRL) level of between 37.3 and 4700 $\mathrm{ng} / \mathrm{mL}$ (mean $1608.2 \pm 1771.6 \mathrm{ng} / \mathrm{mL}$ ) were included in the study. The PRL and other trophic hormones levels were evaluated after 1, 3, 6 and 12 months, and tumour size was evaluated by magnetic resonance imaging examination after 12 months of therapy with cabergoline.

Results: Therapy with cabergoline led to remission of headaches, visual acuity correction, and a significant improvement in libido

\section{STRESZCZENIE}

Wstęp: Gruczolaki przysadki produkujące prolaktynę należą do najczęściej występujących hormonalnie czynnych guzów przysadki. Leczeniem z wyboru w przypadkach prolaktinoma jest leczenie farmakologiczne przy użyciu agonistów receptorów dopaminowych. Najczęściej stosowanym lekiem jest bromokryptyna charakteryzująca się jednak licznymi działaniami ubocznymi. Od kilku lat dobre efekty leczenia uzyskuje się, stosując kabergolinę - selektywnego agonistę receptora dopaminowego o przedłużonym działaniu.

Celem pracy była ocena skuteczności leczenia kabergoliną mężczyzn z makroprolaktinoma na podstawie badań klinicznych, hormonalnych i radiologicznych.

Materiał i metody: Badaną grupę stanowiło 10 mężczyzn w wieku 18-65 lat (średnia 41,9 $\pm 15,01$ ) z obecnością patologicznej masy w przysadce o wymiarach $16,7-40,5$ mm (średnia 29,8 and erection in all patients. In $90 \%$ of patients, PRL normalisation was achieved, just the initial months of therapy. The mean PRL serum concentrations were before, and after 1, 3, 6 and 12 months of therapy respectively, $1608.2 \pm 1771.6 \mathrm{ng} / \mathrm{mL}$ and $263.4 \pm 223.4,136.1 \pm 244.7,91.31 \pm 105.5$ and $27.5 \pm 57.7 \mathrm{ng} / \mathrm{mL}$. A significant tumour size reduction was observed: from 29.8 $\pm 9.4 \mathrm{~mm}$ to $23.2 \pm 9.4 \mathrm{~mm}$, a mean reduction of about $6 \mathrm{~mm}$, or $25.1 \%$ (from $4-48.5 \%$ ). No significant correlation between the mean tumour size and PRL level was observed before or during the treatment. A decreased testosterone level before the therapy was proven, and its gradual increase during the treatment was observed, but after 12 months no normal mean testosterone concentration was achieved.

Conclusions: 1 . The administration of cabergoline to patients with macroprolactinoma is effective in reaching PRL level normalisation as well as in tumour size reduction. 2 . Therapy with cabergoline significantly decreases the clinical symptoms of hyperprolactinemia and neurological and ophtalmological changes associated with the presence of a pathological lesion in the pituitary gland. 3 . Tumour size is not a predictive factor for the effectiveness of therapy with cabergoline.

Key words: macroprolactinoma, cabergoline, therapy evaluation.

$\pm 9,38 \mathrm{~mm}$ ) oraz podwyższonym stężeniem prolaktyny (PRL) 37,34700 ng/mL (średnia 1608,2 $\pm 1771,6$ ng/mL). Stężenia PRL oraz pozostałych hormonów tropowych były oceniane po 1, 3, 6 oraz 12 miesiącach, a ocena wielkości guza była oceniana za pomocą rezonansu magnetycznego po 12 miesiącach leczenia kabergoliną. Wyniki: Leczenie kabergoliną doprowadziło u wszystkich pacjentów do ustąpienia bólów głowy, poprawy ostrości wzroku oraz wyraźnej poprawy w zakresie libido i erekcji. U 90\% pacjentów uzyskano normalizację stężenia PRL już po pierwszych miesiącach leczenia. Średnie stężenia PRL wynosiły przed oraz po 1, 3, 6 i 12 miesiącach leczenia odpowiednio 1608,2 $\pm 1771,6 \mathrm{ng} / \mathrm{mL}$ oraz $263,4 \pm 223,4,136,1 \pm 244,7,91,31 \pm 105,5$ i $27,5 \pm 57,7 \mathrm{ng} / \mathrm{mL}$. Stwierdzono istotne średnie zmniejszenie średnicy guza z 29,8 $\pm 9,4 \mathrm{~mm}$ do $23,2 \pm 9,4 \mathrm{~mm}$, średnio o ok. $6 \mathrm{~mm}$, co stanowi $25,1 \%$ (4-48,5\%). Nie stwierdzono istotnej korelacji między średnią wielkością guza o stężeniem PRL przed oraz w trakcie leczenia. 
Wykazano obniżone stężenie testosteronu przed leczeniem obserwując jego stopniowy wzrost w trakcie leczenia, jednak po upływie 12 miesięcy nie uzyskano prawidłowych średnich stężeń testosteronu.

Wnioski: 1. Stosowanie kabergoliny u pacjentów z makroprolaktinomą jest skuteczne w uzyskaniu normalizacji stężenia prolaktyny, jak również częściowej redukcji wielkości guza.
2. Terapia kabergoliną istotnie zmniejsza kliniczne objawy hiperprolaktynemii oraz wpływa na zmiany neurologiczne i okulistyczne związane z obecnością patologicznej zmiany w przysadce mózgowej. 3. Wielkość guza nie jest czynnikiem predykcyjnym dla efekty wności leczenia kabergoliną.

Słowa kluczowe: makroprolaktinoma, kabergolina, ocena leczenia.

\section{INTRODUCTION}

Pituitary adenomas producing prolactin (PRL), which are called prolactinomas, are hormonally active tumours representing $40 \%$ of all pituitary gland tumourous [1]. With respect to their size, they are designated as either micro- $(<1,0 \mathrm{~cm})$ and macroadenomas $(\geq 1,0 \mathrm{~cm})$ [2]. They appear between the second and fifth decades of life in both sexes, though more often in women $[3,4,5]$. The commonest clinical symptoms caused by hyperprolactinemia in men are: decreased libido, impotence, erectile disorders, and infertility, while galactorrhoea and gynaecomasty are less common $[6,7,8,9]$. This is why men visit a specialist relatively late, usually when symptoms deriving form the pathological mass in the pituitary gland, such as headaches and eyesight disorders, occur. This is why macroadenomas occur more often among men than among women $[10,11,12,13,14]$.

The treatment of choice in pituitary tumours producing PRL, regardless of sex, is pharmacological treatment with dopamine receptors agonists [12]. Neurosurgical methods are introduced in patients resistant to or intolerant of drugs [15]. The aim of the treatment is PRL level normalization, and associated with this, return of proper pituitary gland function, return of fertility and disappearance of both the neurological and the ophtalmological symptoms associated with tumour size regression $[2,11,16]$. Since the 1970s, bromocriptine, an unselective dopamine receptor agonist, has been the basis of pharmacological therapy [17]. By fusion and activation of the D2 receptor, bromocriptine effectively inhibits PRL secretion and reduces the tumour size. It concerns about $50-70 \%$ of patients with macroprolactinoma $[18,19,20,21]$. Some patients suffer from onerous side-effects such as nausea, orthostatic hypotension, severe vertigo and/or drowsiness [22]. These side-effects often lead to the physician to terminating the therapy. Resistance to the treatment also demands the introduction of other drugs to decrease PRL level [21, 23, 24]. Recently, good effects of therapy with cabergoline, a selective agonist of dopamine receptors, have been observed [25, 26]. This drug, used 1-2 times a week because of its long biological half-life ( 65 hours), decreases the PRL level and reduces the tumour size $[27,28$, $29,30]$. As the same time, side-effects occur transiently or not at all [22]. There have been reports in the literature as to the great effectiveness of cabergoline in case of resistance to or intolerance of bromocriptine [15, 31].

The aim of this study was the evaluation of cabergoline therapy efficacy among men suffering from macroprolactinoma based on clinical, biochemical and radiological research.

\section{MATERIAL AND METHODS}

Ten men aged $18-25$ (mean age $41.9 \pm 15.01$ years) treated in Department of Endocrinology, Metabolic Diseases and Internal Diseases, Pomeranian Medical University in Szczecin (PMU) or in the Outpatient Endocrinologic Clinic or directed to the Department of Neurosurgery, PMU in 2008-2010 because of secreting prolactin pituitary gland macroprolactinoma were included in the study. The diagnosis was made on the basis of clinical symptoms, clinical examination, prolactin serum level analysis and pituitary gland MRI examination. Each patient had a pathological mass in the pituitary gland visualized of a size corresponding to a macroadenoma (tumour size between 16.67 and $40.57 \mathrm{~mm}$, mean $28.82 \pm 9.38$ ) and elevated PRL level was observed: from 37.31-4700 ng/mL (mean 1608.17 \pm 1771.58 ).

All patients had the remaining trophic hormones assayed before the therapy onset i.e.: TSH, ACTH, FSH, LH, GH and also cortisol, testosterone and fT4. Because of borderline GH level and lack of inhibition in a glucose test and elevated IGF-1 level, mixed PRL and GH secreting pituitary tumour was diagnosed in one patient. The characteristics of the examined group are set out in Table 1.

The commonest symptoms reported by the patients were: headaches $-4(40 \%)$ patients, worsening of visual acuity -3 (30\%) patients, erectile disorders, decrease of libido - 5 (50\%) patients, deterioration of hairiness and less need to shave -2 (20\%) patients, sleepiness, fatigue $-4(40 \%)$ patients, increased body mass $-2(20 \%)$ patients and gallactorrhoea -1 patient $(10 \%)$. During the initial examination $8(80 \%)$ patients were diagnosed with a pituitary hypofunction within the thyroid hormones axis, $6(60 \%)$ patients within the gonadal axis with a decreased testosterone level and decreased level of at least one of gonadotrophins, and $2(20 \%)$ patients within the adrenal gland axis.

The therapy was based on oral administration of cabergoline preparation (by Pfizer Europe Company) in the initial dose of $0.5 \mathrm{mg}$ twice a week gradually increasing to the dose that effectively decreased PRL level. The treatment continuation and the final dose of the drug depended on the patient's clinical condition improvement and PRL serum concentration.

Having considered the reports about the disorders within heart valves, especially in patients taking more than $3 \mathrm{mg}$ a day (in Parkinson's disease), all patients before the start therapy had an echocardiography performed to exclude valvular disorders and to make it possible to monitor the influence of the drug given for the heart lesions. 
TABLE 1. Characteristics of the examined group of patients suffering from macroprolactinoma

\begin{tabular}{|c|c|c|c|c|c|c|c|c|c|c|c|c|}
\hline No & Initials & $\begin{array}{l}\text { Age in the } \\
\text { moment of } \\
\text { diagnosis } \\
\text { (years) }\end{array}$ & $\begin{array}{l}\text { Max tumour } \\
\text { size in NMR } \\
\quad(\mathrm{mm})\end{array}$ & $\begin{array}{c}\text { PRL } \\
(n g / m L)\end{array}$ & $\begin{array}{c}\text { FSH } \\
(\mathrm{mlU} / \mathrm{mL})\end{array}$ & $\begin{array}{c}\text { LH } \\
(\mathrm{mIU} / \mathrm{mL})\end{array}$ & $\begin{array}{l}\text { Testosterone } \\
\text { (ng/dL) }\end{array}$ & $\begin{array}{c}\text { TSH } \\
(\mu \mathrm{IU} / \mathrm{mL})\end{array}$ & $\begin{array}{c}\text { fT4 } \\
\text { (ng/dL) }\end{array}$ & $\begin{array}{l}\text { Cortisol } \\
\text { ( } \mu g / d L) \\
\text { HR } 8.00\end{array}$ & $\begin{array}{c}\text { ACTH } \\
\text { (pg/mL) } \\
\text { HR } 8.00\end{array}$ & $\begin{array}{c}\mathrm{GH} \\
\text { (ng/mL) }\end{array}$ \\
\hline 1 & W.M. & 53 & 45.5 & 1640 & 5.39 & 5.46 & 3.61 & 5.85 & 0.883 & 9.57 & 68.94 & 0.05 \\
\hline 2 & B.R. & 65 & 24 & 45 & 2.82 & 1.47 & 0.258 & 1.56 & 0.476 & 7.6 & 37.17 & 0.05 \\
\hline 3 & O.C. & 23 & 24 & 837 & 2.46 & 3.5 & 1.6 & 4.28 & 1.17 & 23.66 & 59.73 & 0.1 \\
\hline 4 & K.M. & 18 & 31 & 2318 & 3.94 & 3.82 & 0.103 & 3.03 & 0.343 & 2.45 & 32.39 & 0.05 \\
\hline 5 & B.W. & 32 & 20 & 37.31 & 1.23 & 0.294 & $<0.025$ & 0.129 & 0.664 & $<1$ & 12.8 & 3.1 \\
\hline 6 & K.A. & 55 & 25 & 4700 & 1.89 & 2.13 & 3.43 & 1.09 & 0.955 & 26.2 & 36.81 & 0.5 \\
\hline 7 & Z.Z. & 53 & 20 & 747.1 & 4.06 & 6.9 & 2.99 & 0.439 & 1.87 & 19.69 & 9.26 & 0.13 \\
\hline 8 & K.J. & 43 & 30 & 448.33 & 1.95 & 0.945 & 0.42 & 0.977 & 0.51 & 5.4 & 24.6 & 0.43 \\
\hline 10 & R.M. & 35 & 33 & 628 & 2.79 & 2.69 & 3.13 & 2.27 & 1 & 12.60 & 34.98 & 0.54 \\
\hline MN & & 41.9 & 29.82 & 1608.17 & 2.84 & 2.77 & 1.57 & 2.18 & 0.85 & 12.59 & 35.21 & 0.55 \\
\hline SD & & 15.01 & 9.389 & 1771.58 & 1.35 & 2.32 & 1.55 & 1.79 & 0.44 & 9.41 & 20.84 & 0.98 \\
\hline M & & 42.5 & 27.5 & 792.05 & 2.46 & 2.13 & 1.01 & 1.885 & 0.774 & 9.57 & 34.6 & 0.13 \\
\hline
\end{tabular}

PRL - pituitary adenomas producing prolactin; MN - mean; SD - standard deviation; M - median; Na - not assayed.

TABLE 2. Pituitary adenomas producing prolactin (PRL) concentration and tumour size changes before and during the therapy with Cabergoline

\begin{tabular}{|c|c|c|c|c|c|c|c|c|c|c|c|}
\hline No & Initials & $\begin{array}{c}\text { PRL } \\
\text { (ng/mL) } \\
\text { before } \\
\text { therapy }\end{array}$ & $\begin{array}{c}\text { PRL } \\
\text { (ng/mL) } \\
\text { after } 1 \mathrm{mth}\end{array}$ & $\begin{array}{c}\text { PRL } \\
\text { (ng/mL) } \\
\text { after } \\
3 \text { mths }\end{array}$ & $\begin{array}{c}\text { PRL } \\
\text { (ng/mL) } \\
\text { after } \\
6 \text { mths }\end{array}$ & $\begin{array}{c}\text { PRL } \\
\text { (ng/mL) } \\
\text { after } \\
12 \text { mths }\end{array}$ & $\begin{array}{c}\text { Time to } \\
\text { PRL level } \\
\text { normalization }\end{array}$ & $\begin{array}{l}\text { Max tumour } \\
\text { size before } \\
\text { the therapy }\end{array}$ & $\begin{array}{c}\text { Max } \\
\text { controlled } \\
\text { tumour } \\
\text { size }\end{array}$ & $\begin{array}{c}\text { Max } \\
\text { cabergoline } \\
\text { dose (mg) }\end{array}$ & $\begin{array}{c}\text { Cabergoline } \\
\text { dose while } \\
\text { normal PRL } \\
\text { (mg) }\end{array}$ \\
\hline 1 & W.M. & 1640 & 7,43 & 1,97 & 1,69 & 4,16 & 1 & 45,5 & 41,9 & 2 & 1 \\
\hline 2 & B.R. & 45 & $\mathrm{Na}$ & 0,241 & 0,126 & 0,136 & 3 & 24 & 18 & 1 & 1 \\
\hline 3 & O.C. & 837 & 396,8 & 143,9 & 78,87 & 27,85 & 12 & 24 & 20 & 5 & 3 \\
\hline 4 & K.M. & 2318 & $\mathrm{Na}$ & 703 & 255,8 & 178,9 & ns & 31 & 18 & 7 & \\
\hline 5 & B.W. & 37,31 & $\mathrm{Na}$ & 0,197 & $\mathrm{Na}$ & 0,144 & 3 & 20 & 12,3 & 1 & 1 \\
\hline 6 & K.A. & 4700 & $\mathrm{Na}$ & 229 & 22,34 & 4,73 & 6 & 25 & 24 & 4 & 2 \\
\hline 7 & Z.Z. & 747,1 & 463 & $\mathrm{Na}$ & 136,6 & 25,13 & 12 & 20 & 16 & 4 & 3 \\
\hline 8 & K.J. & 448,33 & 416,6 & 2,26 & $\mathrm{Na}$ & $\mathrm{Na}$ & 3 & 30 & 25,2 & 4 & 3 \\
\hline 10 & R.M. & 628 & $\mathrm{Na}$ & $\mathrm{Na}$ & 232 & 2,4 & 12 & 33 & 19,8 & 4 & 4 \\
\hline MN & & 1608,17 & 263,40 & 136,12 & 91,31 & 27,48 & 6,11 & 29,82 & 23,22 & 3,45 & 2,28 \\
\hline SD & & 1771,58 & 223,40 & 244,72 & 105,52 & 57,74 & 4,59 & 9,389 & 9,376 & 1,86 & 1,09 \\
\hline$M$ & & 792,05 & 396,8 & 5,33 & 50,61 & 4,16 & 3 & 27,5 & 19,9 & 4 & 2,5 \\
\hline
\end{tabular}

MN - mean; SD - standard deviation; M - median; Na - not assayed

TABLE 3. Mean FSH, LH, T, TSH and fT4 before and during the therapy with cabergoline

\begin{tabular}{|c|c|c|c|c|c|c|c|c|c|c|c|c|c|}
\hline & $\begin{array}{c}\text { FSH } \\
\text { before } \\
\text { therapy }\end{array}$ & $\begin{array}{c}\text { FSH } \\
\text { after } 6 \\
\text { mths }\end{array}$ & $\begin{array}{c}\text { FSH } \\
\text { after } 12 \\
\text { mths }\end{array}$ & $\begin{array}{c}\text { LH } \\
\text { before } \\
\text { therapy }\end{array}$ & $\begin{array}{c}\text { LH } \\
\text { after } 6 \\
\text { mths }\end{array}$ & $\begin{array}{c}\text { LH } \\
\text { after } 12 \\
\text { mths }\end{array}$ & $\begin{array}{c}\mathrm{T} \\
\text { before } \\
\text { therapy }\end{array}$ & $\begin{array}{c}\text { T } \\
\text { after } 6 \\
\text { mths }\end{array}$ & $\begin{array}{c}\mathrm{T} \\
\text { after } 12 \\
\text { mths }\end{array}$ & $\begin{array}{c}\text { TSH } \\
\text { before } \\
\text { therapy }\end{array}$ & $\begin{array}{c}\text { TSH } \\
\text { after } 12 \\
\text { mths }\end{array}$ & $\begin{array}{c}\text { fT4 } \\
\text { before } \\
\text { therapy }\end{array}$ & $\begin{array}{c}\text { fT4 } \\
\text { after } 12 \\
\text { mths }\end{array}$ \\
\hline $\begin{array}{l}\text { Mean } \\
\text { level }\end{array}$ & 2.84 & 2.73 & 2.70 & 2.77 & 1.48 & 1.83 & 1.57 & 2.16 & 2.29 & 2.18 & 1.49 & 0.85 & 1.08 \\
\hline SD & 1.35 & 1.84 & 1.73 & 2.32 & 1.14 & 1.33 & 1.55 & 1.58 & 1.51 & 1.79 & 1.80 & 0.44 & 0.295 \\
\hline$M$ & 2.46 & 2.31 & 2.58 & 2.13 & 1.58 & 2.06 & 1.01 & 1.77 & 2.06 & 1.89 & 0.53 & 0.77 & 1.19 \\
\hline
\end{tabular}

SD - standard deviation; M - median. 
In the cases of hypofunction within the particular axes L-tyroxine in doses from 25-125 ug/day and hydrocortisone in doses 20-40 mg/day were administered apart from cabergoline.

In this study a year-long period of therapy with cabergoline was analyzed in patients with macroprolactinoma, although all of them are still under supervision of Outpatient Endocrynologic Clinic. The PRL serum level was assayed before and after 1, 3, 6 and 12 months of treatment, and the level of remaining hormones before and after 6 and 12 months.

Hormonal tests were performed in the Central Laboratory of Autonomous Public Clinical Hospital (APCH) No 1 in Szczecin using immunoenzymatic methods. The normal range for PRL was 1.8-15.9 ng/mL, for FSH 1.5-12.4 mIU/mL, for $\mathrm{LH} 1.7-8.6 \mathrm{mIU} / \mathrm{mL}$, for testosterone $2.8-8.0 \mathrm{ng} / \mathrm{mL}$, for TSH 0.27-4.2 $\mu \mathrm{IU} / \mathrm{mL}$, for free fT4 $0.93-1.7 \mathrm{ng} / \mathrm{dL}$, for cortisol 6.2-19.4 $\mu \mathrm{g} / \mathrm{dL}$, and for ACTH 4.7-48.8 pg/mL. The imaging studies were performed in The Magnetic Resonance and Computer Tomography Laboratory of APCH No 1 in Szczecin or in West Pomeranian District Hospital in Szczecin.

The comparison of statistical significance of hormonal tests results was performed with a nonparametric Wilcoxon rank sum test. The evaluation of correlation of 2 measurable constant features was performed by calculating the Spearman rank correlation factor. The acceptable significance level of type I error ( $p$ - the level of test significance) was chosen as 0.05 .

\section{RESULTS}

Therapy with cabergoline led in all examined patients with macroprolactinoma to the remission of headaches, and significant visual activity improvement, especially in one case, in which the improvement occurred just a few days after the therapy had begun. A significant improvement of sexual functions such as libido and erection occurred. No side effects were observed during therapy with cabergoline.

Table 2 sets out the PRL serum concentration and tumour size in MRI examination during the therapy with cabergoline. A statistically significant reduction of PRL serum level after just a month of treatment was proved. The mean concentration $( \pm$ SD) of PRL level before and after 1, 3, 6 and 12 months of the treatment were respectively $1608.17 \pm 1771.58 \mathrm{ng} / \mathrm{mL}$ and 263.40 $\pm 223.4,136.12 \pm 244.72,91.31 \pm 105.52$ and $27.48 \pm 57.74 \mathrm{ng} / \mathrm{mL}$. In $90 \%$ of all patients normalisation of serum PRL level was reached. Only in the case of one patient, designated with No 4 , did serum PRL concentration not reach the normal range after 12 months of the therapy, although these levels were significantly lower than initially, respectively $178.9 \mathrm{ng} / \mathrm{mL}$ and $2318 \mathrm{ng} / \mathrm{mL}$.

The time from the therapy onset to PRL serum concentration normalization varied between one and 12 months, on average $6.11 \pm 4 / 59$ months. Maximal doses of cabergoline used varied from 1-7 mg per week. The mean $( \pm S D)$ maximal weekly dose of cabergoline was $3.45 \pm 1.86 \mathrm{mg}$. No correlation was observed between the cabergoline dose size and PRL serum concentration during the treatment. However, a significant correlation was observed between cabergoline dose and the time required for PRL serum concentration normalization, i.e. the higher the dose of the medicine, the shorter the time needed for PRL serum normalisation.

A statistically significant mean tumour size reduction from $29.8 \pm 9.4 \mathrm{~mm}$ to $23.2 \pm 9.4 \mathrm{~mm}$ was observed. Figure 1 presents the size of tumour in MRI examination before and after the treatment with cabergoline in particular patients. Reduction of macroadenomas size after 12 months of therapy with cabergoline varied between $4 \%$ and $48.5 \%$. No statistically significant correlation between the mean tumour size before the treatment and the PRL level before and during the treatment was observed. Nor was such a correlation observed between the initial tumour size and the time of reaching prolactin level normalization as well as the administered cabergoline dose.

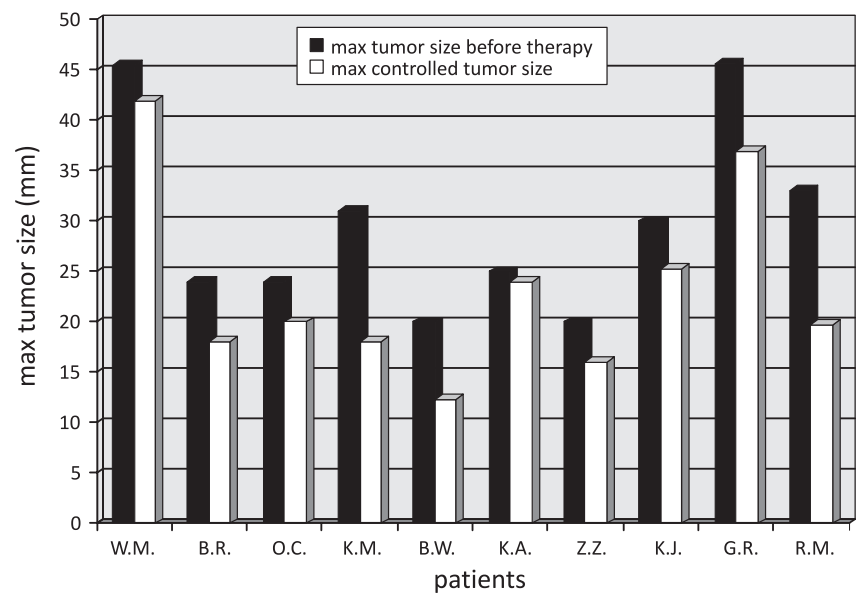

FIGURE 1. Changes in maximal tumour size after 12 months of therapy with cabergoline

The behaviour of the mean serum gonadotropins, testosterone, thyrotropin and thyroxine concentration in examined patients before and after 6 and 12 months of the treatment is presented in Table 3. A decreased mean testosterone level before the treatment was observed, as well as its gradual increase during the cabergoline administration, but after 12 months of the therapy the normal mean testosterone level wasn't reached. No significant correlation was observed between the PRL level and testosterone concentration during the treatment. Neither low mean gonadotrophins (LH and FSH) level before the treatment, nor its significant increase during the cabergoline treatment was observed. The mean serum thyrotropin levels before and during the treatment were within the norms; mean $\mathrm{fT}_{4}$ level before the treatment was decreased and became normal during the cabergoline therapy and substitutional treatment with L-thyroxine.

\section{DISCUSSION}

Pituitary gland adenomas secreting PRL as well as micro- as macroprolactinomas, as the only one from the hormonally active pituitary gland tumours can be treated with conservative therapy $[11,23,32,33]$. It derives as much from biochemical 
as from radiological response to oral pharmacological therapy [23,34]. Dopamine receptors agonists effectively decrease the level of prolactin and reduce the tumour mass, sometimes leading to its disappearance $[26,27,35,36]$. Such effects are not observed in adenomas producing $\mathrm{GH}$, TSH, ACTH or gonadotrophins. Because of this, these tumours demand the surgical treatment [37, 38].

In some cases of hormonally inactive adenomas and other tumours located in sellar-suprasellar region, PRL levels may be elevated due to pressure on dopamine tracts [17, 33, 39]. Most our patients had significantly elevated serum PRL levels and the diagnosis of macroprolactinoma was evident. However, 2 patients had prolactin levels of $37.31 \mathrm{ng} / \mathrm{mL}$ and $45.0 \mathrm{ng} / \mathrm{mL}$ respectively, which are only 2-3 times ULN for serum PRL levels. Absence of PRL response to metoclopramide test and reduced size of tumours in response to cabergoline treatment may confirm the diagnosis of prolactinoma [40]. Lower baseline PRL levels in one of these patients may be a result of previous short-term bromocriptine therapy $[18,19,20,22]$. Pituitary adenomas producing prolactin levels shown in Table 1 $(37.31 \mathrm{ng} / \mathrm{mL})$ were determined 2 weeks after the completion of bromocriptine therapy and baseline levels were given in different units, yielding the result of $1760 \mathrm{mIU} / \mathrm{mL}$ (normal range: $86-324 \mathrm{mIU} / \mathrm{mL}$ ). Hook effect should also be considered but PRL levels following serum dilution were not determined $[14,33,39,40]$.

There is information in the literature about the greater effectiveness of bromocriptine with regards to microadenomas rather than macroadenomas [23]. The administration of selective D2 receptor agonists e.g. cabergoline or quinagolide effectively reduces tumour size as well as leading to PRL level normalisation in patients with micro- and macroprolactinoma [41, 42]. Cabergoline is useful in cases of resistance to bromocriptine or quinagolide [15, 29, 31]. In our study, a high effectiveness of cabergoline in PRL level normalisation was proved (n) in 90\% of patients. Our own research is confirmed by the reports of Biller et al. [25], Pinzone et al. [43] and Ferrari et al. [35] who stated the PRL normalisation in respectively $73 \%, 79 \%$ and $90 \%$ in patients with macroprolactinoma. Colao et al. [36] found PRL level normalisation to be reached by 75.6 and $80 \%$ of men with macroprolactinoma and microprolactinoma respectively during 2 years of therapy.

Our own results are also consistent with the research of other authors, who confirm the normal PRL level return just at the beginning of the therapy $[27,44,45,46,47]$. Ono et al. found up to $83 \%$ of patients reached the normal level during the three months after therapy onset [44]. However, Corsello et al. [45] in the group of 10 patients with giant pituitary tumours observed a significant reduction of PRL level up to $96 \%$ and persistent normalization in 50\% of patients during 3-6 months after the pharmacological therapy had begun.

In our own research we reached a significant reduction of tumour size in all patients, and this reduction was on average $6 \mathrm{~mm}$, i.e. $4-48,5 \%$ (mean $25,1 \%$ ). The data from literature suggests a diverse response of macroadenomas secreting prolactin to cabergoline treatment, ranging from total atrophy of the tumour to reduction of just a few percent [36, 37, 45, 46 , 47]. Corsello et al. [45] found that reduction of the tumour size achieved after 12 months of cabergoline administration was 95\% (in 3 patients), 50\% (in 4 patients) and 25\% (in 2 patients).

Colao et al. obtained a very good response to the therapy $[36,47]$. In one study, cabergoline led to a more than $80 \%$ reduction of tumour size in 14 out of $23(61 \%)$ patients after only 3 months of therapy [36]. In their second study, the reduction was $73.7 \%$ in compared to its maximal size before treatment [47]. Total remission of adenoma was observed in $30 \%$ of examined with macroprolactinoma after 24 months of treatment [36].

Based on data from the literature, it can be stated that two processes during the therapy with dopamine agonists influence the change in tumour size - fibrosis and tumour ischaemia. Menucci et al. [48], in 24 patients treated with neurosurgery, proved the presence of fibrosis in histopathological examination after the surgery. This process was present in $77 \%$ of patients previously treated with bromocriptine, but in only $22 \%$ of patients taking cabergoline. However, Manuchehri et al. [49], based on the evaluation of contrast flow changes in MRI examination, demonstrated a decrease in tumour perfusion and its ischemia, just after the short-term administration of selective dopamine receptor agonists. This can partially explain the better effect of cabergoline in comparison to bromocriptine in attaining a complete remission after neurosurgical treatment.

In our study, the patient who had the biggest tumour size reduction didn't reach the PRL level within the normal range, despite the large dose of cabergoline $(7 \mathrm{mg})$. The symptoms of hypogonadism and low level of testosterone remained, together with normal gonadotropins level. The young age of the patient (18 years) and the lack of fully developed puberty features, inspired to consider the surgery in this patient $[15,32,50,51]$.

Analysing the tumour size and its influence on the PRL level in our own material, we found no correlation between the tumour size before the treatment and the time to reach the PRL normalization. Similarly, Shimon et al. found no such correlation in 12 treated patients with adenomas larger than $4 \mathrm{~cm}$ [52]. Tumour size does not significantly influence PRL concentration changes during therapy, as has been proved by Bolko et al. [53].

In our own study, we found an influence of the dose of administered cabergoline on the time needed to achieve normal serum level of prolactin, i.e. the higher the dose, the shorter the time to reach normalization. However, no correlation between the tumour size and the cabergoline dose needed to reach the normal PRL level was observed. This finding is confirmed by the study of Colao et al. study [36], in which PRL level normalisation during 2 years of treatment was reached via a similar dose of dopamine receptor agonist in $75.6 \%$ and $80 \%$ of men respectively with macroprolactinoma and microprolactinoma. However, research by Verhelst et al. [28] indicated the necessity of a bigger dose of cabergoline in patients with macroprolactinoma compared to those with microprolactinoma, as well 
as with idiopathic hyperprolactinemia. This demands further investigation.

Numerous reports from the literature indicate a good tolerance of cabergoline during the therapy [23]. According to Pontikides et al. [46], a good tolerance and few side-effects occur during the long-term therapy with cabergoline at a dose of $0.5^{-2} \mathrm{mg}$. Biller et al. had a similar observation using 0.5-3.0 mg [25]. However, Colao et al. [47] observed mild nausea lasting for 2 days in 1 patient who had previously had numerous side-effects demanding termination of the therapy with bromocriptine. Also, a high dose of cabergoline ( $7 \mathrm{mg}$ per week) in the research by Shimon et al. [52], administered in the case of giant adenomas therapy, was not accompanied by the presence of side effects and reduced the mean size of the tumour mass by $47 \% \pm 21 \%$. In our study, a patient receiving $7 \mathrm{mg}$ of cabergoline per week also had no side-effects, and the tumour size, despite the lack of prolactin level normalization, was reduced of $48.5 \%$.

The aim of therapy with cabergoline is to obtain remission of the clinical symptoms of hyperprolactinemia as well as of the distress deriving from the presence of the pathological mass in pituitary gland, such as eyesight changes and headaches [14, 34, 47]. According to Pinzone et al. [43], men with macroprolactinoma more often suffer from headaches while sexual dysfunction and testosterone deficiency concern all men regardless of the tumour size [54].

All our patients had a significant improvement in their libido and erection, although the testosterone levels reached after 12 months of therapy were below the normal range. Such result could be associated with the 12 months observation period, because some authors indicate the normalisation of gonadal axis parameters after 24 months of therapy [49, 52]. However, De Rosa et al. [55] reported testosterone level normalisation after just 6 months of therapy.

Prolactin is necessary for the proper spermatogenesis process, and its normal concentration is demanded for the normal testes functioning. However, an excess of this hormone disturbs the gonadal axis function and disturbs the sexual functions including fertility by worsening the sperm quality [56]. Therefore, the return of potency and libido derives from the PRL and secondarily from gonadotrophins and testosterone normalisation. The reduction of tumour size is associated then with headaches remission and field of vision correction [34, 43, 52]. Our own research is consistent with the Corsello et al. study [45], which found a visual acuity improvement and a complete remission of headaches in patients with prolactinoma larger than $4 \mathrm{~cm}$ and a significant improvement of sexual functions in 6 out of eight patients despite a still abnormal testosterone level. An improvement of sexual functions and a $100 \%$ return of fertility was observed by Biller et al. [25]. Fertility seems to return faster if cabergoline is used rather than bromocriptine [57]. Several studies by De Rosa et al. have confirmed gonadal function improvement in $66.7 \%$ of men suffering from hyperprolactinemia, and also testosterone normalisation, return of libido and potency, and a partial improvement of sperm quality after just 6 months of therapy, plus its further amelioration as therapy continues $[55,57,58,59]$.

\section{CONCLUSIONS}

Cabergoline administration in patients with macroprolactinoma is effective in reaching PRL level normalisation as well as in tumour size reduction.

Therapy with cabergoline significantly decreases the clinical symptoms of hyperprolactinemia and the neurological and ophtalmological changes associated with the presence of a pathological lesion in the pituitary gland.

Tumour size is not a predictive factor in the effectiveness of therapy with cabergoline.

\section{REFERENCES}

1. Gillam M.P., Molitch M.E., Lombardi G., Colao A.: Advances in the treatment of prolactinomas. Endocr Rev. 2006, 27 (5), 485-534.

2. Kars M., Dekkers O.M., Pereira A.M., Romijn J.A.: Update in prolactinomas. Neth J Med. 2010, 68 (3), 104-112.

3. Mindermann T., Wilson C.B.: Age-related and gender-related occurrence of pituitary adenomas. Clin Endocrinol (Oxf). 1994, 41 (3), 359-364.

4. Fernandez A., Karavitaki N., Wass J.A.: Prevalence of pituitary adenomas: a community-based, cross-sectional study in Banbury (Oxfordshire, UK). Clin Endocrinol (Oxf). 2010, 72 (3), 377-382.

5. Ciccarelli A., Daly A.F., Beckers A.: The epidemiology of prolactinomas. Pituitary. 2005, 8 (1), 3-6.

6. De Rosa M., Zarrilli S., Di Sarno A., Milano N., Gaccione M., Boggia B. et al.: Hyperprolactinemia in men: clinical and biochemical features and response to treatment. Endocrine. 2003, 20 (1-2), 75-82.

7. Coppola A., Cuomo M.A.: Prolactinoma in the male. Physiopathological, clinical, and therapeutic features. Minerva Endocrinol. 1998, 23 (1), 7-16.

8. Walsh J.P., Pullan P.T.: Hyperprolactinaemia in males: a heterogeneous disorder. Aust NZ J Med. 1997, 27 (4), 385-390.

9. Corona G., Mannucci E., Fisher A.D., Lotti F., Ricca V., Balercia G. et al.: Effect of hyperprolactinemia in male patients consulting for sexual dysfunction. J Sex Med. 2007, 4 (5), 1485-1493.

10. Colao A., Sarno A.D., Cappabianca P., Briganti F., Pivonello R., Somma C.D. et al:: Gender differences in the prevalence, clinical features and response to cabergoline in hyperprolactinemia. Eur J Endocrinol. 2003, 148 (3), 325-331.

11. Melmed S., Casanueva F.F., Hoffman A.R., Kleinberg D.L., Montori V.M., Schlechte J.A. et al.: Endocrine Society. Diagnosis and treatment of hyperprolactinemia: an Endocrine Society clinical practice guideline. J Clin Endocrinol Metab. 2011, 96 (2), 273-288.

12. Braucks G.R., Naliato E.C., Tabet A.L., Gadelha M.R., Violante A.H.: Clinical and therapeutic aspects of prolactinoma in men. Arq Neuropsiquiatr. 2003, 61 (4), 1004-1010.

13. Delgrange E., Raverot G., Bex M., Burman P., Decoudier B., Devuyst F. et al.: Giant prolactinomas in women. Eur J Endocrinol. 2013, 22, 170 (1), 31-38.

14. Maiter D., Delgrange E.: Therapy of endocrine disease: the challenges in managing giant prolactinomas. Eur J Endocrinol. 2014, 170 (6), R213-227.

15. Wong A., Eloy J.A., Couldwell W.T., Liu J.K.: Update on prolactinomas. Part 2: Treatment and management strategies. J Clin Neurosci. 2015, 22 (10), 1568-1574.

16. Krysiak R., Okopień B., Marek B., Szkróbka W.: Gruczolak przysadki wydzielający prolaktynę. Przegl Lek. 2009, 66 (4), 198-205.

17. Child D.F., Nader S., Mashiter K., Kjeld M., Banks L., Fraser T.R.: Prolactin studies in "functionless" pituitary tumours. Br Med J. 1975, 1 (5958), 604-606.

18. Molitch M.E., Elton R.L., Blackwell R.E., Caldwell B., Chang R.J., Jaffe R. et al.: Bromocriptine as primary therapy for prolactin-secreting macroadenomas: results of a prospective multicenter study. J Clin Endocrinol Metab. 1985, 60 (4), 698-705.

19. Van't Verlaat J.W., Croughs R.J., Hendriks M.J., Bosma N.J.: Results of primary treatment with bromocriptine of prolactinomas with extrasellar extension. Can J Neurol Sci. 1990, 17 (1), 71-73. 
20. Waśko R., Bocian-Sobkowska J., Krzyżagórska E., Horst-Sikorska W., Kozak W.: Wyniki leczenia bromokryptyną chorych z guzami przysadki typu prolaktinoma. Now Lek. 1994, 63 (5), 16-23.

21. Di Sarno A., Landi M.L., Cappabianca P., Di Salle F., Rossi F.W., Pivonello R. et al.: Resistance to cabergoline as compared with bromocriptine in hyperprolactinemia: prevalence, clinical definition, and therapeutic strategy. J Clin Endocrinol Metab. 2001, 86 (11), 5256-5261.

22. Cho K.R., Jo K.I., Shin H.J.: Bromocriptine therapy for the treatment of invasive prolactinoma: the single institute experience. Brain Tumor Res Treat. 2013, 1 (2), 71-77.

23. Colao A., Di Sarno A., Guerra E., De Leo M., Mentone A., Lombardi G.: Drug insight: Cabergoline and bromocriptine in the treatment of hyperprolactinemia in men and women. Nat Clin Pract Endocrinol Metab. 2006, 2 (4), 200-210.

24. Molitch M.E.: Pharmacologic resistance in prolactinoma patients. Pituitary. 2005, 8 (1), 43-52.

25. Biller B.M.K., Molitch M.E., Vance M.L., Cannistraro K.B., Davis K.R., Simons J.A. et al.: Treatment of prolactin secreting macroadenoma with once-weekly dopamine agonist cabergoline. J Clin Endocrinol Metab. 1996, 81 (6), 2338-2343.

26. Colao A., Di Sarno A., Landi M.L., Scavuzzo F., Cappabianca P., Pivonello R. et al: : Macroprolactinoma shrinkage during cabergoline treatment is greater in naive patients than in patients pretreated with other dopamine agonists: a prospective study in 110 patients. J Clin Endocrinol Metab. 2000, 85 (6), 2247-2252.

27. Rastogi A., Bhansali A., Dutta P., Singh P., Vijaivergiya R., Gupta V. et al.: A comparison between intensive and conventional cabergoline treatment of newly diagnosed patients with macroprolactinoma. Clin Endocrinol (Oxf). 2013, 79 (3), 409-415.

28. Verhelst J., Abs R., Maiter D., van den Bruel A., Vandeweghe M., Velkeniers B. et al:: Cabergoline in the treatment of hyperprolactinemia: a study in 455 patients. J Clin Endocrinol Metab. 1999, 84 (7), 2518-2522.

29. Colao A., Di Sarno A., Sarnacchiaro F., Ferone D., Di Renzo G., Merola B. et al.: Prolactinomas resistant to standard dopamine agonists respond to chronic cabergoline treatment. J Clin Endocrinol Metab. 1997, 82 (3), 876-883.

30. Webster J.: Clinical management of prolactinomas. Baillieres Best Pract Res Clin Endocrinol Metab. 1999, 13 (3), 395-408.

31. Delgrange E., Maiter D., Donckier J.: Effects of the dopamine agonist cabergoline in patients with prolactinoma intolerant or resistant to bromocriptine. Eur J Endocrinol. 1996, 134 (4), 454-456.

32. Wang A.T., Mullan R.J., Lane M.A., Hazem A., Prasad C., Gathaiya N.W. et al.: Treatment of hyperprolactinemia: a systematic review and meta-analysis. Syst Rev. 2012, 24 (1), 33.

33. Wong A., Eloy J.A., Couldwell W.T., Liu J.K.: Update on prolactinomas. Part 1: Clinical manifestations and diagnostic challenges. J Clin Neurosci. 2015, 22 (10), 1562-1567.

34. Alsubaie S., Almalki M.H.: Cabergoline treatment in invasive giant prolactinoma. Clin Med Insights Case Rep. 2014, 19, 7, 49-51.

35. Ferrari C., Paracchi A., Mattei A.M., de Vincentiis S., D'Alberton A., Crosignani $P$.: Cabergoline in the long-term therapy of hyperprolactinemic disorders. Acta Endocrinol (Copenh). 1992, 126 (6), 489-494.

36. Colao A., Vitale G., Cappabianca P., Briganti F., Ciccarelli A., De Rosa M. et al.: Outcome of cabergoline treatment in men with prolactinoma: effects of a 24-month treatment on prolactin levels, tumor mass, recovery of pituitary function, and semen analysis. J Clin Endocrinol Metab. 2004 89 (4), 1704-1711.

37. Bevan J.S., Webster J., Burke C.W., Scanlon M.F.: Dopamine agonists and pituitary tumor shrinkage. Endocr Rev. 1992, 13 (2), 220-240.

38. Kopczak A., Renner U., Karl Stalla G.: Advances in understanding pituitary tumors. F1000Prime Rep. 2014, 2 (6), 5.

39. Vilar L., Fleseriu M., Bronstein M.D.: Challenges and pitfalls in the diagnosis of hyperprolactinemia. Arq Bras Endocrinol Metabol. 2014, 58 (1), 9-22.
40. Zgliczyński W., Zdunowski P.: Hyperprolactinaemia - pitfalls in PRL assessment. Endokrynol Pol. 2005, 56 (6), 980-985.

41. Waśko R., Dymalska-Kubasik L., Horst-Sikorska W., Sowiński J.: Norprolaca new drug in the treatment of prolactinoma type adenomas resistant to bromocriptine therapy. Endokrynol Pol. 1999, 50 (2), 139-146.

42. Zgliczyński W., Jeske W., JanikJ. et al.: The use of Norprolac (Novartis) - a selective agonist of D2-dopamine receptor-in treatment of macroprolactinoma. Endokrynol Pol. 2000, 51 (2), 225-236.

43. Pinzone J.J., Katznelson L., Danila D.C., Pauler D.K., Miller C.S., Klibanski A. et al:: Primary medical therapy of micro- and macroprolactinomas in men. J Clin Endocrinol Metab. 2000, 85 (9), 3053-3057.

44. Ono M., Miki N., Kawamata T., Makino R., Amano K., Seki T. et al.: Prospective study of high-dose cabergoline treatment of prolactinomas in 150 patients. J Clin Endocrinol Metab. 2008, 93 (12), 4721-4727.

45. Corsello S.M., Ubertini G., Altomare M., Lovicu R.M., Migneco M.G., Rota C.A. et al: Giant prolactinomas in men: efficacy of cabergoline treatment. Clin Endocrinol (Oxf). 2003, 58 (5), 662-670.

46. Pontikides N., Krassas G.E., Nikopoulou E., Kaltsas T.: Cabergoline as a first-line treatment in newly diagnosed macroprolactinomas. Pituitary. 2000, 2 (4), 277-281.

47. Colao A., Di Sarno A., Landi M.L., Cirillo S., Sarnacchiaro F., Facciolli G. et al.: Long-term and low-dose treatment with cabergoline induces macroprolactinoma shrinkage. J Clin Endocrinol Metab. 1997, 82 (11), 3574-3579.

48. Menucci M., Quiñones-Hinojosa A., Burger P., Salvatori R.: Effect of dopaminergic drug treatment on surgical findings in prolactinomas. Pituitary. 2011, 14 (1), 68-74.

49. Manuchehri A.M., Sathyapalan T., Lowry M., Turnbull L.W., Rowland-Hill C. Atkin S.L.: Effect of dopamine agonists on prolactinomas and normal pituitary assessed by dynamic contrast enhanced magnetic resonance imaging (DCE-MRI). Pituitary. 2007, 10 (3), 261-266.

50. Vroonen L., Jaffrain-Rea M.L., Petrossians P., Tamagno G., Chanson P., Vilar L. et al: Prolactinomas resistant to standard doses of cabergoline: a multicenter study of 92 patients. Eur J Endocrinol. 2012, 167 (5), 651-662.

51. Maiter D., Primeau V:: 2012 update in the treatment of prolactinomas. Ann Endocrinol (Paris). 2012, 73 (2), 90-98.

52. Shimon I., Benbassat C., Hadani M.: Effectiveness of long-term cabergoline treatment for giant prolactinoma: study of 12 men. Eur J Endocrinol. 2007, 156 (2), 225-231.

53. Bolko P., Jaskuła M., Waśko R., Wołuń M., Sowiński J.: The assessment of cabergoline efficacy and tolerability in patients with pituitary adenomas prolactinoma type. Pol Arch Med Wewn. 2003, 109 (5), 489-495.

54. Badal J., Ramasamy R., Hakky T., Chandrashekar A., Lipshultz L.: Case report: Persistent erectile dysfunction in a man with prolactinoma. F1000Res. 2015, 15, 4, 13

55. De Rosa M., Zarrilli S., Vitale G., Di Somma C., Orio F., Tauchmanova' L. et al.: Six months of treatment with cabergoline restores sexual potency in hyperprolactinemic males: an open longitudinal study monitoring nocturnal penile tumescence. J Clin Endocrinol Metab. 2004, 89 (2), 621-625.

56. Ciccarelli A., Guerra E., De Rosa M., Milone F., Zarrilli S., Lombardi G. et al.: PRL secreting adenomas in male patients. Pituitary. 2005, 8 (1), 39-42.

57. De Rosa M., Colao A., Di Sarno A., Ferone D., Landi M.L., Zarrilli S. et al.: Cabergoline treatment rapidly improves gonadal function in hyperprolactinemic males: a comparison with bromocriptine. Eur J Endocrinol. 1998, 138 (3), 286-293.

58. De Rosa M., Zarrilli S., Di Sarno A., Milano N., Gaccione M., Boggia B. et al:: Hyperprolactinemia in men: clinical and biochemical features and response to treatment. Endocrine. 2003, 20 (1-2), 75-82.

59. De Rosa M., Ciccarelli A., Zarrilli S., Guerra E., Gaccione M., Di Sarno A. et al.: The treatment with cabergoline for 24 month normalizes the quality of seminal fluid in hyperprolactinaemic males. Clin Endocrinol (Oxf). 2006, 64 (3), 307-313. 